Indonesian Journal of Theology 2/2 (December 2014): 179-205

\title{
KESATUAN DAN PERBEDAAN DALAM GEREJA PERDANA ${ }^{1}$
}

\author{
Victor Christianto
}

\begin{abstract}
Two interesting questions in relation with the Early Church history are: the extent of unity or diversity among Peter, James, and Paul; and also how Paul's thoughts have shaped direction of the Church in later periods. Answers to these questions will be very helpful in order that we can give a proper response to "Paulinism", an accusation which some non-Christian thinkers often have towards Christians (c.f. Tom Jacobs). Such an accusation (Paulinism) basically says that Christianity is a religion created by St. Paul, not Jesus Christ. In order to respond to such an accusation, in this article the writer will describe: what was the historical truth concerning relation between St. Paul and the Jerusalem Church generally, and especially relation between St. Paul and James the brother of Jesus. It will be shown that the relationship between St. Paul and the Jerusalem Church did not indicate separation or conflict, but unity in diversity. This article is written with a purpose to open a new constructive way of interfaith dialogue; nonetheless this is just a preliminary research therefore this article may not give a last word or a definitive answer to the problems as posed above.
\end{abstract}

Keywords: Paul, James, James the Just, Ferdinand Baur, Early Church, unity in diversity, New Testament.

1 Tulisan ini merupakan cuplikan dari tesis Magister Teologi di STT Satyabhakti dengan judul: Tinjauan Kritis terhadap Pandangan Eisenman tentang Kontradiksi antara Paulus dan Yakobus (September 2014). Penulis ingin menyampaikan terima kasih kepada Dr. Paskalis Edwin Nyoman Paska yang telah membimbing penulis dan memberikan saran-saran yang berharga selama penulisan tesis, serta kepada Drs. Gani Wiyono, M.Th, Th.M. yang telah memberikan beberapa referensi yang bermanfaat. Secara khusus penulis berterimakasih kepada Dr. Bambang Noorsena, S.H., M.H. atas diskusi dengan penulis serta saran-saran yang diberikan. Banyak terima kasih juga kepada dua mitra bebestari atas saransaran yang sangat berguna terhadap versi awal artikel ini. 


\begin{abstract}
Abstrak
Salah satu pertanyaan yang cukup menarik untuk didiskusikan dalam hubungannya dengan sejarah Gereja Perdana adalah sejauh mana ada kesatuan atau perbedaan antara pandangan Petrus, Yakobus dan Paulus, serta sejauh mana pemikiran Paulus menentukan arah perkembangan Gereja di periode-periode selanjutnya. Jawaban atas pertanyaan tersebut akan sangat membantu kita dalam memberikan respons terhadap tuduhan Paulinisme yang kerap dilontarkan oleh beberapa penulis non-Kristen khususnya di Indonesia terhadap ajaran Kekristenan (cf. Tom Jacobs). Tuduhan Paulinisme itu intinya mengatakan bahwa Kekristenan adalah agama buatan Paulus, bukan Yesus Kristus. Untuk menanggapi tuduhan tersebut, dalam artikel ini penulis hendak menjelaskan bagaimana sebenarnya relasi antara Paulus dengan Gereja Yerusalem secara umum, dan relasi antara Paulus dengan Yakobus saudara Yesus secara khusus. Ditunjukkan bahwa relasi antara Paulus dan Gereja Yerusalem tidak mengindikasikan adanya perpecahan, melainkan kesatuan dalam perbedaan (unity in diversity). Artikel ini bertujuan untuk membuka dialog lintas-iman yang konstruktif, meskipun merupakan karya awal sehingga mungkin tidak memberikan kata akhir atau jawaban definitif terhadap persoalan ini.
\end{abstract}

Kata-Kata Kunci: Paulus, Yakobus, James the Just, Ferdinand Baur, Gereja Perdana, Gereja Yerusalem, kesatuan dalam perbedaan, Perjanjian Baru.

\title{
Pendahuluan
}

Salah satu pertanyaan yang cukup menarik untuk didiskusikan dalam hubungannya dengan sejarah Gereja Perdana adalah sejauh mana ada kesatuan atau perbedaan antara pandangan Petrus, Yakobus dan Paulus, serta sejauh mana pemikiran Paulus menentukan arah perkembangan Gereja di periode-periode selanjutnya. Jawaban atas pertanyaan tersebut akan sangat membantu kita dalam memberikan respons terhadap tuduhan Paulinisme yang kerap dilontarkan oleh beberapa penulis non-Kristen khususnya di Indonesia terhadap ajaran Kekristenan. ${ }^{2}$ Tuduhan Paulinisme itu intinya hendak mengatakan

2 Tom Jacobs, Paulus - Hidup, Karya dan Teologinya. Cet.-2 (Yogyakarta: Penerbit Yayasan Kanisius, 1983; Jakarta: B.P.K. Gunung Mulia, 1984), 110-113. 
bahwa Kekristenan adalah agama buatan Paulus, bukan Yesus Kristus. Dengan perkataan lain, tuduhan ini menyatakan bahwa Paulus adalah pendiri sebenarnya dari Kekristenan. Dan tampaknya tuduhan ini merupakan sikap kalangan muslim pada umumnya, tidak hanya di Indonesia, lihat misalnya pernyataan berikut: "All Christian doctrines are the work of Paul, based on the desire to gain favor -and new converts-among the non Jews of his time. By incorporating pagan beliefs into the teachings of Jesus, Paul achieved phenomenal success in his ministry, but at the price of tearing down everything that true monotheism stands for." Karena itu menjadi kewajiban umat Kristen khususnya kalangan teolog untuk menanggapi tuduhan tersebut secara proporsional (1 Pet 3:15). Dalam artikel ini penulis hendak menjelaskan bagaimana sebenarnya relasi antara Paulus dengan Gereja Yerusalem secara umum, dan relasi antara Paulus dengan Yakobus saudara Yesus secara khusus, dengan tujuan untuk menjawab apakah benar tuduhan Paulinisme tersebut. Ditunjukkan bahwa relasi antara Paulus dan Gereja Yerusalem tidak mengindikasikan adanya perpecahan, melainkan kesatuan dalam perbedaan (unity in diversity).

Memang harus diakui bahwa gagasan tentang adanya kesatuan antara Paulus, Petrus dan Yakobus bukanlah hal yang baru. Demikian juga gagasan bahwa ada perbedaan di antara ketiganya juga tidak baru. Bahkan juga sudah banyak studi tentang adanya kesatuan dalam perbedaan di antara pemikiran para rasul dalam Gereja Perdana, terutama sejak karya James Dunn, Unity in Diversity. ${ }^{4}$ Namun sejauh pengetahuan penulis, studi-studi tersebut dilakukan lebih untuk keperluan kajian sejarah Gereja Perdana, tapi bukan untuk membangun sebuah respons yang proporsional terhadap tuduhan Paulinisme yang dilontarkan oleh kalangan muslim. Jadi belum ada atau relatif masih sedikit artikel yang ditulis untuk memberi jawab terhadap keragu-raguan kalangan muslim terhadap iman Kristiani. Sebaliknya artikel ini bertujuan untuk membuka dialog lintas-iman yang lebih konstruktif, meskipun merupakan karya awal sehingga mungkin tidak memberikan kata akhir atau jawaban definitif terhadap persoalan ini.

Catatan: Romo Tom Jacobs adalah seorang pastor dan teolog yang cukup dikenal di Indonesia, terutama pada dekade 70-90an.

3"The True Founder of Christianity;" diambil dari

http://www.teachislam.com/dmdocuments/45/The $\% 20$ True $\% 20$ Founder $\% 20$ of \%20Christianity.pdf ; Internet; diakses 8 Januari 2015.

${ }^{4}$ James D.G. Dunn, Unity and Diversity in the New Testament: An Inquiry into the Character of Earliest Christianity, Second ed., 3 ${ }^{\text {rd }}$ printing (Tottenham Road, London: SCM Press, 1990). 


\section{Asumsi tentang Historisitas}

Pertama-tama, ada baiknya kita mulai dengan menetapkan dulu beberapa asumsi mengenai historisitas kitab-kitab dalam PB. Dokumen Pontifical Biblical Commission 1993 mengatakan tentang historical criticism sebagai berikut: "Itu adalah suatu metode kritik, karena dalam setiap langkahnya (dari kritik teks hingga kritik redaksi) itu berjalan dengan bantuan kriteria ilmiah yang berupaya untuk menjadi seobjektif mungkin." ${ }^{, 5}$ Dalam menggunakan metode historis kritis ini, penulis mengambil asumsi dasar bahwa Kitab Suci dilihat sebagai kitab yang kanonik dan dianggap sebagai norma (ukuran dasar) kebenaran. Implikasi dari asumsi ini adalah bahwa seluruh kitab dalam Kitab Suci khususnya Perjanjian Baru, dapat dipertanggungjawabkan baik secara historis maupun teologis. Misalnya kisah-kisah baik yang dilakukan oleh Yesus Kristus dan para rasul dalam ketiga Injil Sinoptik, Injil Yohanes, dan Kisah Para Rasul dapat diterima sebagai pernah terjadi dalam sejarah.

Asumsi dasar tersebut bertolak dari dua pemahaman atau presuposisi yaitu: a. menghormati otoritas Kitab Suci, b. metode studi sejarah yang memadai senantiasa memberikan penghormatan kepada naskah yang lebih kuno dan dekat dengan peristiwa yang dilaporkan. Jadi seandainya pun kita menganggap tabib Lukas kurang akurat dalam melaporkan peristiwa-peristiwa dalam Kisah Para Rasul, setidaknya kita mesti memberikan respek yang lebih kepada tulisan Lukas yang dibuat hanya berjarak beberapa tahun dengan peristiwa yang dilaporkan daripada kepada naskah-naskah yang ditulis beberapa abad setelahnya, seperti misalnya Pseudo-Clementine.

Memang asumsi dasar yang diambil penulis agak kurang lazim, karena metode historis kritis modern seringkali meragukan historisitas Kisah Para Rasul. ${ }^{6}$ Sebagai contoh baik Ferdinand Baur maupun Robert Eisenman menolak historitas Kisah Para Rasul dan sebaliknya menerima Pseudo-Clementine sebagai naskah yang lebih berotoritas, padahal ada tiga alasan yang melemahkan PseudoClementine sebagai suatu rujukan historis: a. ditulis sekitar abad ketiga, b. bercorak roman, c. dan jelas-jelas bernuansa Ebionit. Khoo

${ }^{5}$ David E. Aune, ed., The Blackwell Companion to the New Testament (West Sussex: John Wiley \& Sons Ltd., 2010), 101-104.

${ }^{6}$ Mengenai historisitas Kisah Para Rasul, lihat misalnya W. Ward Gasque, "The Historical Value of the Book of Acts: The Perspective of British Scholarship," Theologische Zeitschrift 28 (1972), 177-196; diambil dari http://www.biblicalstudies.org.uk/; Internet; diakses 8 Januari 2015. 
mendefinisikan ajaran Ebionisme yang dianggap heretikal adalah sebagai berikut:

Ebionism was one of the early heresies in the church which attacked the person of Christ especially with regard to His divine nature. They tanght that Jesus of Nazareth was a good teacher and prophet, but that he was no way divine.

Demikian pula, sebagian ahli menganggap bahwa Injil Yohanes kurang bernilai historis dibandingkan dengan ketiga Injil Sinoptik. Namun sebagaimana ditunjukkan oleh Dodd, ${ }^{8}$ Injil Yohanes berasal dari tradisi yang lebih kuno dalam sejarah Gereja Perdana, sehingga nilai historisnya tidak menjadi lebih rendah dibandingkan dengan Injil Sinoptik.

Dengan perkataan lain, asumsi dasar yang diambil penulis di atas berakibat setidaknya 3 hal:

1. Dalam menggunakan metode historis kritis, hendaknya seorang peneliti sejarah Gereja Perdana menjaga sedemikian sehingga tidak sampai melupakan metode studi sejarah yakni menghargai naskah yang ditulis lebih dekat dengan peristiwa.

2. Sebaiknya seorang peneliti tidak buru-buru meragukan atau bersikap skeptis terhadap historisitas Kisah Para Rasul, kalau sumber lain yang dimiliki hanyalah Pseudo-Clementine.

3. Dalam membaca kitab-kitab dalam PB, masing-masing uraian dilengkapi dengan uraian di tempat lain dalam PB. Misalnya jika kita membaca perselisihan yang dikisahkan dalam Kisah Para Rasul pasal 15, maka perlu dilengkapi dengan membaca surat Galatia, demikian seterusnya. Dengan demikian kita akan memperoleh gambaran yang lebih utuh akan sejarah Gereja Perdana.

\section{Perkembangan pemikiran tentang Paulus dalam sejarah}

Sebelum kita membahas mengenai bagaimana sebenarnya relasi antara Paulus dengan Gereja Yerusalem secara umum, dan relasi antara Paulus dengan Yakobus saudara Yesus secara khusus,

${ }^{7}$ Khoo, 7. Untuk uraian yang agak lengkap tentang kaum Ebionit, lihat Oskar Skarsaune, The Ebionites, in Skarsaune \& Hvalvik (eds.), Jewish Believers in Jesus, 427-462.

${ }^{8}$ D.A. Carson, "Historical Tradition of the Fourth Gospel: After Dodd, What?” R.T. France \& David Wenham, eds., Gospel Perspectives, Vol. 2: Studies of History and Tradition in the Four Gospels (Sheffield: JSOT Press, 1981): 83-145. 
ada baiknya kita melihat beberapa interpretasi atas Paulus sepanjang sejarah Gereja. Kaum Ebionit, suatu kelompok sekte Yahudi konservatif dari Kekristenan yang asal-usulnya tidak jelas, menganggap Paulus sebagai Yahudi apostat (murtad). Kelompok sempalan dari gereja Kristen Yahudi ini memisahkan diri dari Kekristenan non-Yahudi (Gentile) diperkirakan sejak revolusi Bar Kokhba (132-135 M). Mereka memelihara Sabat dan sunat, menjunjung tinggi hukum Musa, namun menolak surat-surat Paulus dan keilahian Yesus, serta membedakan antara Yesus sejarah dan Kristus yang kekal. Pada sisi ekstrim lain ada Marcion, bidat dari abad kedua Masehi. Ia membuat gerakan radikal berdasarkan injil kasih karunia Perjanjian Baru. Marcion memuja Paulus. Kanon Marcion adalah versi yang diedit dari Injil Lukas dan 10 surat-surat Paulus. Para Bapa Gereja dari abad-abad permulaan, baik Yunani maupun Latin, bereaksi terhadap distorsi-distorsi ekstrem semacam itu dengan menerima secara teguh otoritas apostolik dari ketiga belas surat Paulus. Tidak disebutkan mengenai surat Ibrani, yang secara tradisi juga dianggap sebagai Corpus Paulinum. ${ }^{9}$

Beberapa waktu sesudah periode tersebut, Agustinus yang sudah lama mencari kebenaran berbalik kepada Kristus setelah membaca Roma 13:13-14. Agustinus melihat pertobatan dan introspeksi sebagai cara hidup Kristen, dan membuka jalan pada ordo-ordo biara sepanjang Abad Pertengahan. Sekitar sepuluh abad sesudahnya, seorang biarawan Jerman bernama Martin Luther menemukan kembali doktrin Paulus tentang pembenaran oleh iman yang tidak tergantung dari usaha manusia (works) dan dengan jalan demikian memicu Reformasi Protestan. Bagi Luther, doktrin pembenaran merupakan doktrin utama dalam Kekristenan. ${ }^{10}$

Dari sejak terbitnya esai "Die Christuspartei in der korinthischen Gemeinde" dalam Tübinger Zeitschrift für Theologie (1831), Ferdinand C. Baur tampil sebagai salah satu tokoh monumental dari penafsiran Perjanjian Baru. Tesisnya kemudian diperluas dalam buku berjudul Paulus der Apostel Jesu Christi pada 1845. Baur berargumen bahwa Kekristenan rasuli ditandai oleh perpecahan radikal di antara gereja Yerusalem dan Gereja-gereja hasil kerja misi Paulus. ${ }^{11}$ Gereja di Yerusalem, yang dipimpin oleh Petrus dan Yakobus, berupaya

${ }^{9}$ Don N. Howell, Jr., "Pauline thought in the History of Interpretation," BSAC 150:599 (Jul 1993): 304-305.

10 Ibid., 305-306.

11 Tema perpecahan atau "parting of ways" ini kemudian dikembangkan oleh Dunn; lihat James D.G. Dunn, The Partings of the Ways: Between Christianity and Judaism and their significance for the Character of Christianity. Second ed. (London: SCM Press, 2006), 1-6. 
mempertahankan ketaatan kepada Taurat dan tradisi sunat, sementara Paulus menganggap tradisi Yahudi sebagai suatu yang asing bagi Injil kebebasan yang sejati. Konflik ini tampak cukup jelas dalam surat Galatia dan Korintus. Skematisasi Baur mengikuti dialektika Hegel. Tesis berupa legalisme Yahudi dan antitesis berupa kebebasan Pauline menghasilkan sintesis abad kedua berupa katolikisme awal. Baur kerap mengutip dengan yakin literatur Pseudo-Clementine dari abad keempat dalam membangun teorinya. Baur antara lain mengatakan:

That Christianity, in the universal historical importance which it achieved, was the work of the Apostle Paul is undeniably a matter of bistorical fact; but in what manner he brought this about, how we are to conceive of his relations with the elder Apostles, whether it was in harmony with them or in contradiction and opposition to them... ${ }^{12}$

Dugaan Baur tersebut dapat dijelaskan dalam bentuk skema berikut, meskipun terlalu sederhana:

Tabel 1. Spektrum Kekristenan Perdana ${ }^{13}$

\begin{tabular}{|c|c|c|c|}
\hline \multicolumn{2}{|c|}{$\begin{array}{l}\text { Kekristenan Non-Yahudi } \\
\text { (Gentile) }\end{array}$} & \multicolumn{2}{|c|}{ Kekristenan Yahudi } \\
\hline $\begin{array}{c}\text { Jemaat Kristen } \\
\text { non-Yahudi }\end{array}$ & Paulus & $\begin{array}{l}\text { Petrus dan ke- } \\
11 \text { Rasul }\end{array}$ & Judaizers $^{14}$ \\
\hline
\end{tabular}

Meskipun dugaan-dugaan literer dari Mazhab Tübingen kemudian ditolak secara resmi karena terlampau radikal, teori sejarahnya terus memberikan pengaruh dengan derajat yang berbedabeda dalam studi-studi Perjanjian Baru. ${ }^{15}$

Perlu kiranya dicatat di sini bahwa hipotesis sejarah Baur sendiri dapat dilacak mundur sebagai hasil dari perdebatan pemikiran teologis di Jerman, antara kaum rasionalis yang berusaha menjelaskan mukjizat-mukjizat dalam Kitab Suci dari sudut pandang ilmiah, dan kaum supranaturalis yang berusaha mempertahankan kepercayaan akan mukjizat-mukjizat tersebut. R.P. Dunn menulis tentang Baur sebagai berikut:

12 Ferdinand C. Baur, Paul: The Apostle of Jesus Christ, 1845. Vol. I, second ed., diterjemahkan oleh Eduard Zeller (London: Williams \& Norgate, 1876), 3-4.

${ }^{13}$ Dunn, The Partings of the Ways, 5.

14 Yang dimaksud dengan kaum Judaizers adalah golongan Farisi yang masuk Kristen, namun masih berusaha memaksakan agar semua orang Kristen juga menaati hukum Taurat termasuk sunat. Lihat Kis. 15:1,5.

${ }^{15}$ Howell, Jr., 307-308. 
... he recognized in the so-called Ebionites the same Judaizing spirit with which Paul had to contend, and employed in illustrating the earlier period the pseudo-Clementine Ebionistic writings of a subsequent age. ... On the same grounds he had already begun to suspect the authenticity of the Acts of the Apostles. ${ }^{16}$

Di antara para peneliti belakangan, S.G.F. Brandon sangat dekat dengan Baur dalam hal menjaga fitur-fitur utama dari hipotesis Tübingen tapi dengan suatu perbedaan penting yaitu Brandon mengusulkan Yakobus saudara Yesus (James the Just) sebagai pemimpin utama dan jiwa Kekristenan Yahudi, bukan Petrus. Di sisi lain, sejumlah peneliti mengusulkan bahwa penentang Paulus berada di luar Gereja Yerusalem. Namun demikian, dugaan bahwa Yakobus adalah pemimpin kelompok paling legalistik Kekristenan Perdana dan penentang Paulus tetap merupakan anggapan yang sering diterima oleh para pelajar. ${ }^{17}$

Pada pergantian abad ke-20 sebuah pendekatan baru terhadap Paulus dipicu oleh religionsgeschichtliche Schule (atau school of religion history) Salah satu pelopor dalam bidang ini adalah Bousset. Namun demikian, pengaruh dari pemikiran ini jauh berkurang dalam dekadedekade terakhir sejak adanya penemuan Naskah-naskah Qumran dan riset-riset yang lebih luas dalam material-material Yahudi dari periode intertestamental dan Perjanjian Baru. Keyahudian Paulus sedang dalam proses untuk ditemukan kembali. Pemikiran-pemikiran Bultmann yang juga tergolong dalam mazhab religionsgeschichtliche juga ditinggalkan akibat penemuan Naskah-naskah Laut Mati. ${ }^{18}$

Meskipun cukup dekat dengan pendekatan school of religion history, karena keduanya melihat pengaruh Yunani yang dominan dalam Paulus, mazhab liberal menekankan hubungan antara Paulus dan Yesus.

Salah satu pemikir lain yaitu Ramsay, awalnya menerima pandangan Tübingen tentang surat-surat Paulus dan kesejarahan Kisah Para Rasul, namun kemudian secara bertahap dia meninggalkan pandangan Baur dan menerima Lukas sebagai sejarawan. Dalam tulisan-tulisannya ia menggunakan Kisah Para Rasul sebagai suatu

${ }^{16}$ R.P. Dunn, “The Tübingen Historical School,” BSac 19:73 (Jan. 1862): 85.

17 J. Julius Scott, Jr., "Parties in the Church of Jerusalem as seen in the book of Acts", JETS 18:4 (Fall 1975): 217 [jurnal on-line]; diambil dari http://galaxie.com/journals; Internet; diakses 24 Februari 2014.

${ }^{18}$ Howell, Jr., 309-310. 
dokumen sejarah yang teliti tentang latar belakang kehidupan Paulus. ${ }^{19}$

Paulus sendiri menyebut dirinya sebagai "orang Ibrani asli" (Yahudi di antara Yahudi) dan adalah seorang Farisi sebelum bertobat (Flp. 3:5-6; Kis. 23:6, 26:5-6). Meskipun pemikiran Paulus berubah saat pertobatannya, ia tidak pernah menyangkal keyahudiannya. Bahkan ia rindu akan keselamatan saudara-saudaranya dalam daging (Rm. 3:1-2; 9:1-5; 10:1). Karena itu, adalah mengejutkan bahwa para sarjana Perjanjian Baru cenderung mengabaikan atau mengecilkan pengaruh Yahudi dalam pemikiran Paulus. ${ }^{20}$ Dengan penemuan Naskah-naskah Laut Mati dan minat yang baru terhadap Pseudepigrapha Perjanjian Lama, Midrash, Targum, dan literatur rabinik, terjadi pergeseran dalam tahun-tahun belakangan ini ke arah yang lebih mengakui karakter Yahudi dari teologi Paulus dan teologi Yohanes. Para peneliti yang menekankan keyahudian Paulus telah secara umum memusatkan perhatian pada salah satu dari 3 area Yudaisme abad pertama: Yudaisme Apokaliptik, Yudaisme Helenistik, dan Yudaisme Palestinian/rabinik. ${ }^{21}$

\section{Apakah Alkitab Mengindikasikan Adanya Kontradiksi antara Kekristenan Yahudi dan Kekristenan Paulus?}

Pertanyaan di atas merupakan salah satu implikasi dari pandangan F.C. Baur, Robert Eisenman dan sebagian pemikir muslim, khususnya dalam hubungannya dengan penerimaan akan kerasulan Paulus. Dalam hal ini penulis tidak bermaksud menyamaratakan begitu saja pandangan Baur, Eisenman ${ }^{22}$ dan para pemikir muslim

${ }^{19}$ Ibid., 316.

20 Sebagian ahli termasuk Eisenman, tampaknya menyatakan bahwa Paulus adalah seorang Romawi, mengutip Kis. 22:25. Lihat Robert Eisenman, "Paul as Herodian", JHC 3/1 (Spring):110-122 [jurnal on-line]; diambil dari http://www.depts.drew.edu/jhc/eisenman.html; Internet; diakses 17 Februari 2014. Memang hal ini benar, namun Paulus memperoleh kewarganegaraan Rum bukan karena perbudakan tapi mungkin karena hadiah kepada keluarganya, dan dia juga sekaligus orang Yahudi. Seorang penulis menyatakan: "It is most likely that citizenship was bestowed upon the family by a general or Emperor, Pompey being the strongest possibility..." Lihat Sean A. Adams, "Paul the Roman Citizen," in Stanley E. Porter (ed.), Paul: Jew, Greek, and Roman (Leiden, Brill, 2008), 320.

${ }^{21}$ Howell, Jr., 317. Lihat juga Brad H. Young, Paul The Jewish Theologian: A Pharisee among Christians, Jews, and Gentiles.

22 Robert Eisenman, James the Brother of Jesus: The Key to Unlocking the Secrets of Early Christianity and the Dead Sea Scrolls (Middlesex, England: Penguin Books, 1997), 78-79 
tersebut, melainkan penulis ingin menarik benang merah di antara pandangan mereka khususnya dalam hubungannya dengan penerimaan mereka akan kerasulan Paulus. Kita dapat menuliskan ringkasan pemikiran tersebut dalam tabel berikut: kolom kiri adalah sikap para pemikir Muslim pada umumnya dan kolom kanan adalah pandangan kaum Ebionit.

Tabel 2. Perbandingan pandangan pemikir Muslim, Eisenman dan kaum Ebionit

\begin{tabular}{|l|l|l|}
\hline Muslim $^{23}$ & Eisenman & Ebionit \\
\hline - Menolak keilahian & -menyamakan Gereja & -Menolak keilahian \\
& Perdana dengan & Yesus \\
& Ebionit, atau dengan & \\
& kata lain juga: & \\
& Menolak keilahian & \\
Yesus & -meragukan & -hanya menerima 4 \\
historisitas Kisah Para & Injil \\
\hline $\begin{array}{l}\text {-menolak penebusan } \\
\text { Yesus, menolak } \\
\text { pembenaran oleh } \\
\text { iman }\end{array}$ & $\begin{array}{l}\text { Rasul } \\
\text {-menganggap Psendo- }\end{array}$ & \\
& $\begin{array}{l}\text { Clementine lebih } \\
\text { berotoritas }\end{array}$ & \\
dibandingkan Kisah & \\
Para Rasul & \\
\hline $\begin{array}{l}\text { - meragukan surat- } \\
\text { surat Paulus }\end{array}$ & $\begin{array}{l}\text {-menolak kerasulan } \\
\text { Paulus }\end{array}$ & -menolak kerasulan \\
\hline -menolak Trinitas & -menganggap Paulus & -melakukan Taurat \\
& sebagai Herodian & \\
\hline
\end{tabular}

Dalam hal ini, pandangan Baur agak lebih moderat dibandingkan ketiga yang disebut dalam tabel di atas, namun demikian patut dicatat di sini bahwa Baur adalah salah satu yang pertama menyatakan bahwa Pauluslah yang merupakan pendiri sebenarnya dari Kekristenan. Terlebih lagi jika diingat bahwa Baur adalah salah satu pelopor dari studi tentang Kekristenan Yahudi, sementara Kekristenan Yahudi dalam perkembangan sejarah Gereja Perdana dapat diasosiasikan dengan kaum Nazarene dan Ebionit. ${ }^{24}$

23 "The True Founder of Christianity;" diambil dari http://www.teachislam.com/dmdocuments / 45/The $\% 20$ True $\% 20$ Founder $\% 20$ of \%20Christianity.pdf; Internet; diakses 8 Januari 2015.

${ }^{24}$ David Lincicum, "F.C. Baur's place in the Study of Jewish Christianity;" diambil dari http://www.davidlincicum.files.wordpress.com/2012/12/fc-baur-onjewish-christianity.pdf; Internet; diakses 11 Januari 2015. 
Jadi dengan melihat Tabel 2 di atas, tampaknya ada cukup alasan untuk menemukan kemiripan yang agak mencolok antara pemikiran sebagian pemikir Muslim, Baur dan Eisenman dengan pemikiran kaum Ebionit. Tentang para pemikir musim, bahkan keraguan akan keilahian Yesus dan kerasulan Paulus dapat ditemui dengan mudah dalam dialog-dialog di manapun. Misalnya saja seorang teman penulis pernah menulis pesan singkat (sms) seperti berikut: "Mungkin ada Yesus historis, tapi sebagai manusia biasa, tidak ada kaitannya sebagai penebus dosa manusia karena itu hanya karangan Paulus saja." Atau jika ada yang ingin melihat pandangan umum umat Muslim, bisa membaca buku karya Nabeel Jabbour. ${ }^{25}$

Jika kita dapat sepakat bahwa ada kemiripan yang mencolok antara beberapa pemikir muslim, Baur dan Eisenman, maka kiranya cukup beralasan untuk mempertimbangkan suatu garis spektrum yang saya usulkan dengan nama: skala Ebionit. Lihat Diagram 1 di bawah ini:

\section{Diagram 1. Skala Ebionit}

0: Ortodoks 4:Ebionit

Dengan bantuan skala Ebionit tersebut, kita dapat menggolongkan berbagai pemikiran sebagai berikut:

Tabel 3. Tabel Skala Ebionit

\begin{tabular}{|c|l|l|}
\hline Skala Ebionit & Deskripsi & Contoh yang mungkin \\
\hline 0 & $\begin{array}{l}\text { Ajaran Gereja Ortodoks, } \\
\text { sama sekali tidak terpengaruh } \\
\text { Ajaran Ebionit (non- } \\
\text { Ebionite) }\end{array}$ & $\begin{array}{l}\text { Surat-surat Paulus, } \\
\text { Kisah Para Rasul, } \\
\text { Keempat Injil }\end{array}$ \\
\hline 1 & $\begin{array}{l}\text { Sedikit terpengaruh Ebionit } \\
\text { (weakly influenced by Ebionite) }\end{array}$ & Bart Ehrman (?) \\
\hline 2 & $\begin{array}{l}\text { Agak terpengaruh (semi- } \\
\text { Ebionite) }\end{array}$ & Ferdinand Baur (?) \\
\hline 3 & $\begin{array}{l}\text { Terpengaruh kuat dengan } \\
\text { Ebionit (strongly influenced by } \\
\text { Ebionite) }\end{array}$ & Pemikir muslim, \\
Robert Eisenman \\
\hline 4 & Ebionit murni (pure Ebionite) & Ebionit \\
\hline
\end{tabular}

${ }^{25}$ Nabeel T. Jabbour. Memandang Sabit melalui Mata Salib (Bandung: Pionir Jaya, 2010), 189-212. 
Tentunya diagram dan tabel Skala Ebionit tersebut diusulkan dengan tujuan untuk membantu memetakan spektrum pemikiran di antara para pemikir modern, khususnya para peneliti sejarah Gereja Perdana, dan tidak bermaksud menjadi jawaban definitif akan masalah ini. Bart Ehrman dikategorikan dalam skala Ebionit 1 dengan pertimbangan bahwa dalam beberapa bukunya termasuk Lost Scriptures $^{26}$ dan juga Lost Christianities, ia tampaknya berusaha memulihkan ajaran-ajaran heretik seperti Ebionisme, Marcionisme, dan Gnostik dengan memberikan label yang lebih "lunak", yakni Kekristenan yang hilang (Lost Christianities). Untuk tinjauan kritik terhadap buku Bart Ehrman tersebut, silakan lihat makalah Rodney J. Decker. $^{27}$

Sekarang kita kembali kepada pertanyaan yang menjadi judul bagian ini: "Apakah Alkitab Mengindikasikan Adanya Kontradiksi antara Kekristenan Yahudi dan Kekristenan Paulus?" Sebelum menjawab pertanyaan tersebut, pertama-tama mesti diingat bahwa umat Yahudi pada masa Yesus melakukan pelayanan di bumi terbagibagi dalam beberapa golongan (misalnya: Farisi, Saduki, golongan Imam, ahli Taurat, Eseni, Zealot, Samaria dll.) ${ }^{28}$ Demikian pula dari catatan Alkitab tampaknya Gereja Perdana tidak bersifat homogen, melainkan terdiri atas berbagai kelompok, di antaranya: (a) kelompok para rasul, (b) kelompok Yakobus, (c) kelompok Helenis (Kis. 6:1), (d) kelompok murid yang berasal dari kaum Farisi, (e) kelompok Kristen Yahudi yang menaati Taurat, (f) kelompok Kristen asal Yunani (Gentile), (g) kelompok Apolos, dst. Kelompok-kelompok ini sebagian hanya terdapat di jemaat Yerusalem, Antiokhia, atau Korintus, tapi mungkin juga kelompok-kelompok ini mempengaruhi kota-kota lainnya (lih. Kis. 13:45,50; 14:2,19; 17:5,13; 18:12; 20:3). Meskipun kadang-kadang di antara berbagai kelompok tersebut terjadi friksi atau pergesekan, seperti yang diceritakan Paulus dalam surat Galatia, namun secara umum pergesekan yang ada dapat ditengahi dengan surat pastoral, pertemuan atau konsensus, seperti misalnya Sidang di Yerusalem (Kis. 15). Dengan kata lain, tampaknya kita dapat mengatakan bahwa memang terjadi pengelompokan dalam Gereja Perdana, mulai dari yang penganut Taurat garis keras (Kristen

${ }^{26}$ Bart D. Ehrman, Lost Scriptures: Books that did not make it to the New Testament (New York: Oxford University Press Inc., 2003).

${ }^{27}$ Rodney J. Decker, The Rehabilitation of Heresy: Part 2, "Misquoting" Earliest Christianity, Journal of Ministry and Theology 13:2 (Fall 2009), 57-95.

${ }^{28}$ John Stambaugh \& David Balch, Dunia Sosial Kekristenan Mula-mula. Cet.-2. Diterjemahkan oleh Stephen Suleeman (Jakarta: PT BPK Gunung Mulia, 1997), 111-117. 
Yahudi) dengan kelompok yang mesianik, hingga yang agak bernuansa Yunani. Namun, pengelompokan tersebut tidak sampai menjadi sumber perpecahan, meskipun data-data menunjukkan memang ada golongan ekstrim (kaum Judaizers) yang ingin memaksakan Taurat dan sunat kepada umat Kristen yang berasal dari kaum non-Yahudi (Kis. 15:1,5). Kelompok inilah yang disebut Paulus sebagai "saudara-saudara palsu" dalam Gal. 2:4, dan kemungkinan berasal dari kaum Farisi (Kis. 15:1, 5).

Dalam Sidang di Yerusalem, tampak peran Yakobus yang menonjol dan bersifat menentukan dalam mengambil sikap terhadap saudara-saudara Kristen yang berasal dari non-Yahudi. Meskipun demikian Yakobus tampaknya hanya menyinggung peraturan tentang makanan (yang mungkin berkaitan dengan perintah untuk anak-anak Nuh), ${ }^{29}$ dan menghindari pembicaraan tentang apakah semua umat Kristen yang bukan Yahudi harus disunat atau tidak. Namun secara umum tampaknya Yakobus setuju untuk membebaskan umat Kristen non-Yahudi dari kewajiban untuk menaati Taurat. Sekalipun demikian, penulis lain yaitu Nicholas Taylor berpendapat bahwa Dekrit Apostolik (Apostolic Decree) dirumuskan oleh Yakobus, Petrus dan Barnabas setelah berkonsultasi dengan para pemimpin gereja dalam rangka membangun landasan untuk makan bersama antara umat Kristen Yahudi dan non-Yahudi di Antiokhia. ${ }^{30}$

Masalah lain yang muncul mungkin berasal dari "kalangan Yakobus" yang tampaknya cenderung memisahkan diri dari atau tidak mau makan bersama umat Kristen yang non-Yahudi (Gal. 2:12). ${ }^{31}$ Tidak begitu jelas apakah memang itu merupakan ajaran dari Yakobus, atau karena merupakan tradisi dari umat Yahudi yang tidak mau menajiskan diri dengan bangsa-bangsa asing, namun jelas hal ini membuat Petrus bersikap agak ragu-ragu (Gal. 2:11). Paulus tidak dapat bersikap tinggal diam tapi justru mesti menegur Petrus dengan keras. Tampak dari teks ini bahwa bagi Paulus, hidup dalam Kristus berarti bebas untuk berkomunikasi maupun makan bersama,

${ }^{29}$ Justin Taylor, Asal-usul Agama Kristen. Diterjemahkan oleh F.A. Suprapto (Yogyakarta: Penerbit Kanisius, 2008), 206-207.

30 Nicholas Taylor, "Paul, Antioch and Jerusalem: A Study in Relationships and Authority in Earliest Christianity," Journal for the Study of the New Testament, Supplement Series 66 (Sheffield: Sheffield Academic Press, 1992), 141. Pembahasan yang lain mengenai Apostolic Decree bisa dilihat di C.K. Barrett, On Paul: Essays on His Life, Work, and Influence in the Early Church (London: T\&T Clark Ltd., 2003), 88-90.

31 Schmithals yakin bahwa kalangan Yakobus tersebut berasal dari Yahudi atau Kekristenan Yahudi Gnostik. Lihat Walter Schmithals, Paul and James. Studies in Biblical Theology no. 46 (Great Britain: SCM Press Ltd., 1965), 106. 
sekalipun itu dengan umat Kristen non-Yahudi yang dianggap kafir oleh umat Yahudi.

Sedikit catatan tambahan tentang Yakobus saudara Yesus. Menurut tradisi Injil Sinoptik maupun Yohanin, saudara-saudara Yesus bersikap kurang percaya atau skeptis terhadap pelayanan Yesus sebagai Mesias, namun tampaknya sikap ini berubah sejak kebangkitan Yesus. Ini tersirat misalnya dalam Mark. 3:31-33 di mana ibunya dan saudara-saudara Yesus memanggil Yesus yang sedang mengajar di tengah-tengah umat (bnd. Mat. 12:46-48, Luk. 8:19). Demikian juga dalam Yoh. 7:3 saudara-saudara Yesus seperti menyuruh Yesus membuktikan kemesiasan-Nya di depan para muridNya, bahkan dalam ayat 7:5 disebutkan bahwa saudara-saudara Yesus tidak percaya kepada-Nya. Namun menurut Paulus, Yesus juga menampakkan diri kepada Yakobus setelah Dia bangkit (1 Kor. 15:7). ${ }^{32} \mathrm{Hal}$ inilah mungkin yang menyebabkan saudara-saudara Yesus, khususnya Yakobus, diterima dalam gereja Perdana sebagai tokoh-tokoh yang dihormati baik oleh Petrus maupun Paulus. Misalnya, Petrus merasa perlu untuk "melapor" kepada Yakobus saat dia dibebaskan dari penjara oleh malaikat (Kis. 12:17). Sementara itu Paulus tampaknya sempat bertemu dengan Yakobus beberapa kali, dan malah menyebutnya sebagai salah satu "sokoguru" jemaat (Kis. 21:18; Gal. 1:19; Gal. 2:9). Bahkan menurut Bruce, mungkin Yakobus menjadi satu-satunya pemimpin gereja Yerusalem yang masih tinggal di Yerusalem, saat murid-murid Yesus yang lain termasuk Petrus melakukan misi pekabaran Injil di luar Yerusalem. ${ }^{33}$

Dengan demikian, tampaknya Yakobus memang dalam suatu masa menjadi figur utama dalam Gereja Perdana khususnya di Yerusalem. Namun, tidak ada dasar yang cukup untuk menyimpulkan bahwa dia juga adalah tokoh pemimpin gerakan-gerakan militan dan radikal Yahudi termasuk Zealot, Eseni, Sicarii atau Ebionit (sebagaimana disarankan misalnya oleh Robert Eisenman ${ }^{34}$ ).

Sebagai gambaran tentang Gereja Perdana, umat Kristen Perdana berasal dari lingkungan yang kultur religiusnya dekat dengan golongan kaum Eseni. ${ }^{35}$ Dalam lingkungan itu anggota-anggota baru diakui dalam komunitasnya melalui proses inisiasi yang menjadi ciri

32 Tampaknya kita dapat menyimpulkan bahwa pada saat kunjungan terakhir-Nya ke Yerusalem, Yesus telah berdamai dengan Yakobus saudara-Nya. Lihat Bruce Chilton, preface to Sean Freyne, Retrieving James/Yakov, the Brother of Jesus: From Legend to History. Center for the Study of James the Brother, Institute of Advanced Theology (New York: Bard College, 2008), 4.

${ }^{33}$ F.F. Bruce, Peter, Stephen, James, and John: Studies in Early Non-Pauline Christianity (Grand Rapids, Michigan: Wm. B. Eerdmans Publ. Co., 1980), 86-110.

${ }^{34}$ Eisenman, 78-79.

35 Justin Taylor, 283. 
penyucian khusus. Kekuatan utama komunitas ini, yang disediakan bagi anggota baru secara ketat, berupa perjamuan kudus. Apa yang baru dalam umat Kristen dibandingkan dengan kaum Eseni adalah bahwa mereka menyampaikannya melalui kabar baik tentang wafat dan kebangkitan Yesus yang menyelamatkan. Selain itu, kelompok Eseni yang asli tampak menghindari komunikasi dan pergaulan dengan orang-orang Yahudi pada umumnya dan terutama dengan orang-orang non-Yahudi. Sementara itu umat Kristen Perdana bersikap terbuka dan menerima orang yang baru bertobat yang berasal dari non-Yahudi, meskipun ada juga sebagian dari umat Kristen Yahudi yang menjaga jarak dengan umat Kristen non-Yahudi. Jadi dapat dikatakan bahwa dalam Alkitab tidak terdapat indikasi kontradiksi antara jemaat Kristen Yudea dan jemaat Kristen Paulus, sekalipun terjadinya pengelompokan memang tak terhindarkan. Hal ini dapat dibuktikan dari dokumen-dokumen tulisan para Bapa Rasuli seperti Klemens dan lain-lain, ${ }^{36}$ di mana mereka mengakui kerasulan baik Petrus, Yakobus, Yohanes maupun Paulus. Artinya mereka dapat menerima semua tokoh ini sebagai para rasul dan pelopor umat Kristen. Demikian pula terdapat kesatuan teologis (unity) dalam surat-surat para Bapa Rasuli tersebut, sebagaimana disimpulkan oleh Gonzalez: "But this diversity of outlook should not lead us to think that there was not in the church of the time a certain unity of doctrine and thought. On the contrary, in certain aspects one finds a surprising uniformity." 37 Karena tulisan-tulisan para Bapa Rasuli itu jauh lebih kuno daripada naskah Pseudo-Clementine, ${ }^{38}$ maka dengan demikian baik gagasan Baur yang didasarkan atas Pseudo-Clementine menjadi kehilangan dasar. Senada dengan pemikiran tersebut, Schmithals juga menyatakan dalam bukunya bahwa "since the time of the Tübingen school our scholars have taken for granted as the presupposition of all their studies of primitive Christianity that there were weighty theological antagonism between Paul and James. This foregone conclusion, accepted as a matter of course, is in urgent need of re-examination." 39

Dari pemaparan ini, dapat disimpulkan sebagai berikut: "Meskipun memang terjadi pengelompokan dan friksi dalam Gereja Perdana, baik di Yerusalem, Antiokhia, Korintus, Galatia dan tempat-

\footnotetext{
${ }^{36}$ Lightfoot \& Harmer.

${ }^{37}$ Justo L. Gonzalez, A History of Christian Thought, rev. ed. vol. 1: From the Beginnings to the Council of Chalcedon (Nashville: Abingdon Press, 1987), 95.

38 Alexander Roberts \& James Donaldson, Ante-Nicene Fathers: The Writings of the Fathers Down to A.D. 325. vol. 8, rev. ed. (Peabody, Massachussets: Hendrickson Publishers Inc., 1994).

${ }^{39}$ Schmithals, 104. (Italic oleh penulis)
} 
tempat lain, namun hal tersebut tidak sampai menjadi perpecahan dalam tubuh Gereja Perdana."

\section{Relasi antara Paulus dan Kekristenan Yahudi: Kesatuan dalam Perbedaan}

Salah satu pertanyaan yang terkait dengan diskusi di atas adalah bagaimana jelasnya relasi antara Paulus dan Kekristenan Yahudi dalam Gereja Perdana. Dalam hal ini setidaknya ada 3 kemungkinan jawaban, yaitu: (a) Tidak ada pertentangan atau kontroversi yang signifikan antara Paulus dan Kekristenan Yahudi (kitab-kitab dalam Perjanjian Baru dianggap sepenuhnya seragam dalam teologi); (b) Ada kontroversi yang kuat antara Paulus dan Kekristenan Yahudi yang cenderung mengarah ke perpecahan; (c) Memang ada friksi dalam Gereja Perdana namun secara keseluruhan ada kesatuan di antara teologi Pauline maupun Kekristenan Yahudi (unity in diversity).

Dalam hubungan ini ada beberapa pernyataan James D.G. Dunn yang dapat dianggap condong ke arah kemungkinan (b) di atas, antara lain sebagai berikut: (1) "The letter of James is the most Jewish, the most undistinctively Christian document in the NT." (Surat Yakobus adalah yang paling bernuansa Yahudi, dokumen Kristen yang paling khas dalam Perjanjian Baru. $)^{40}$; (2) Menurut Dunn, apa yang tercermin dalam Surat Yakobus adalah "controversy within Christianity" (kontroversi dalam Kekristenan) ${ }^{41}$; (3) Dunn juga menemukan suatu bentuk Kekristenan Yahudi yang berada dalam spektrum Kristen pada masa pelayanan misi Paulus, namun yang menampilkan karakter yang sangat dekat dengan Ebionisme yang kemudian $^{42}$; (4) menurut Dunn "it is evident that there was a much deeper divide between Paul and the Jewish Christianity emanating from Jerusalem than at first appears." (adalah jelas bahwa terdapat perbedaan yang jauh lebih dalam antara Paulus dan Kekristenan Yahudi yang berasal dari Yerusalem daripada yang tampak di permukaan $)^{43}$; (5) menurut Dunn, diamnya jemaat Kristen Yerusalem saat Paulus disidangkan di depan Sanhedrin menyiratkan sikap antipati yang mendasar dari jemaat Kristen Yahudi terhadap Paulus dan ajarannya ${ }^{44}$; (6) Demikian pula tidak disebutnya sumbangan yang

\footnotetext{
40 James D.G. Dunn, 251.

41 Ibid, 251.

42 Ibid, 253.

43 Ibid. 254.

${ }^{44}$ Ibid., 256.
} 
dikumpulkan oleh Paulus bagi jemaat Kristen Yerusalem mungkin menunjukkan bahwa: Kekristenan Yahudi yang memandang dirinya sendiri begitu kuat sebagai keturunan Yahudi dan menempatkan dirinya sendiri begitu kuat melawan Paulus dan misi non-Yahudi yang bebas-dari-Taurat berada di jalur menuju Ebionisme. ${ }^{45}$

Namun, ada jawaban lain yang mengarah ke kemungkinan (c), sebagaimana akan dijelaskan berikut ini. Meskipun Dunn menyatakan bahwa meskipun Paulus tampaknya mengalami "kekalahan" pengaruh di Antiokhia, namun tampaknya secara umum Petrus dapat menerima ajaran Paulus yang tersirat dari cara Petrus tidak membantah Paulus dalam perselisihan di Antiokhia. Sikap Petrus ini cukup konsisten dengan sikapnya yang terbuka terhadap umat non-Yahudi misalnya terhadap Kornelius (Kis. 10:31), pembelaannya akan baptisan Kornelius, serta sikapnya yang sejalan dengan Paulus dalam Sidang di Yerusalem ketika menghadapi kaum Judaizers (Kis. 15:5, 15:9-11). ${ }^{46}$ Sikap moderat Petrus ini ternyata diikuti oleh Gereja Perdana dalam perjalanan selanjutnya, terbukti bahwa gerakan Ebionisme tidak diterima melainkan ditolak sebagai suatu bidat. ${ }^{47}$ Di sini dapat didefinisikan bahwa doktrin kaum Judaizers tersebut mengajarkan bahwa "faith plus work equals to salvation" (iman ditambah perbuatan sama dengan keselamatan), dan karena itu merupakan ajaran yang berbeda dengan iman Kristiani ortodoks yang menekankan pembenaran oleh iman. ${ }^{48}$

Dunn juga menegaskan: kita dapat menarik garis tegas perbedaan antara Ebionisme dan dokumen-dokumen Kristen Yahudi dari Perjanjian Baru itu sendiri. ${ }^{49}$ Dengan kata lain, gerakan Kekristenan Yahudi dalam Gereja Perdana maupun Perjanjian Baru tidak dapat disamakan dengan gerakan Ebionisme yang bersifat heretik dari abadabad sesudahnya.

Persoalan mengenai kemungkinan pertentangan antara Kekristenan Yahudi dan Kekristenan non-Yahudi (Gentile) ini tampaknya berakar dari penggunaan istilah Kekristenan Yahudi itu sendiri. Namun jelas bahwa istilah Kekristenan Yahudi bukanlah

\footnotetext{
45 Ibid., 257.

46 Untuk pembahasan yang agak lengkap tentang kaum Judaizers, lihat Schmithals, 103-117.

${ }^{47}$ Harry A. Peyton, "The Heresies of the Pharisaical Jewish Christian Ebionites," [artikel on-line]; diambil dari http://www.doctrinesofchrist.com/The $\% 20$ Heresies $\% 20$ of $\% 20$ the $\% 20$ Pharisaical \%20Jewish\%20Ebionites.pdf; Internet; diakses 17 April 2014.

48 Jeffrey Khoo, "Heresies Ancient and Modern," [artikel on-line]; diambil dari http://www.febc.edu.sg/assets/pdfs/studyresource/heresies.pdf; Internet; diakses 17 April 2014.

${ }^{49}$ Dunn, Unity and Diversity, 258.
} 
suatu frase yang dapat dijumpai dalam Perjanjian Baru. Menurut Paget, istilah Kekristenan Yahudi (Jewish Christianity atau Jewish Christian) digunakan pertama kali oleh F.C. Baur dan kemudian pada buku karya Gustav Hoennicke. ${ }^{50}$ Sementara itu riwayat Kekristenan Yahudi dipaparkan dengan ringkas oleh Hugh J. Schonfield. ${ }^{51}$ Jadi istilah Kekristenan Yahudi tampaknya baru muncul sekitar 2 abad yang lalu.

Sedangkan mengenai hubungan antara Paulus dan pemimpin jemaat di Yerusalem, Bauckham mencatat bahwa Paulus sangat menghargai mereka sebagai sokoguru (“pillars") jemaat (lih. Gal. 2:9), bahkan urutan penyebutan oleh Paulus mengindikasikan bahwa Yakobus lebih utama daripada Petrus dan Yohanes. Bauckham juga menulis bahwa menurut Klemens dari Aleksandria, setelah kenaikan Yesus ke surga, Petrus, Yakobus (anak Zebedeus) dan Yohanes mengangkat Yakobus saudara Yesus sebagai bishop di Yerusalem (Eusebius, Hist. eccl. 2.1.3). Yakobus muncul sekilas dalam Kis. 1:14, selanjutnya hilang sampai di ayat 12:17, dan kemudian baru muncul lagi sebagai seorang tokoh sentral dalam Sidang di Yerusalem (lih. Kis. 15:7-11). Hal ini mungkin merupakan cara Lukas untuk menunjukkan bahwa Yakobus secara efektif menggantikan Petrus sebagai pimpinan Gereja Yerusalem. ${ }^{52}$ Bahwa Yakobus merupakan tokoh yang sangat penting dalam Gereja Perdana tampaknya sulit dipungkiri, khususnya jika membaca Kis. 21:18. Ada juga rujukan mengenai penunjukan Yakobus sang Adil sebagai penerus Yesus dalam Injil Tomas (Gospel of Thomas) ayat 12. ${ }^{53}$ Selain itu, cukup menarik untuk dicatat bahwa meskipun Paulus menyebutnya dengan gelar saudara Tuhan (Gal. 1:19), namun Yakobus sendiri

${ }^{50}$ James Carleton Paget, "The Definition of the Terms Jewish Christian and Jewish Christianity in the History of Research," in Oskar Skarsaune \& Reidar Hvalvik (eds.), Jewish Believers in Jesus: The Early Centuries (Peabody, Massachusetts: Hendrickson Publishers Inc., 2007), 22.

${ }^{51}$ Hugh J. Schonfield, The History of Jewish Christianity: From the First to the Twentieth Century (Duckworth, London: Vine of David, 1936).

52 Richard Bauckham, "James and Jerusalem Community," in Skarsaune \& Hvalvik (eds.), Jewish Believers in Jesus, 66-67.

53 Menurut Injil Tomas ayat 12, ketika murid-murid-Nya bertanya kepada Yesus, "Siapa yang akan menjadi pemimpin kami?" Yesus kemudian menjawab: "Di manapun kamu berada, pergilah kepada Yakobus Sang Adil (James the Just), untuk siapa langit dan bumi telah dijadikan." Diterjemahkan dari teks ayat 12 dalam Elaine Pagels, "The Text of the Gospel of Thomas," (Polebridge Press, 2004) [artikel on-line]; diambil dari http://www.holybooks.com/wpcontent/uploads/Gospel-of-Thomas-Scholars-Version.pdf; Internet; diakses 3 Agustus 2014. 
merendahkan dirinya dan menyebut dirinya sendiri sebagai hamba Tuhan Yesus (Yak. 1:1). ${ }^{54}$

Karena itu, adanya bukti-bukti yang menunjukkan bagaimana Petrus membela kaum non-Yahudi yang menjadi Kristen maupun sikap Paulus yang menghormati ketiga sokoguru jemaat di Yerusalem merupakan indikasi kuat akan adanya saling pemahaman - atau jika meminjam istilah Dunn: "unity in diversity" (Kesatuan dalam Perbedaan). Dalam hubungan ini, sangat menarik untuk mencatat bahwa Philip Schaff telah membuat kategorisasi terhadap teologi para rasul sebelum 100 Masehi sebagai berikut: (1) Yakobus dan Injil Taurat, (2) Petrus dan Injil Pengharapan, (3) Paulus dan Injil Iman, (4) Yohanes dan Injil Kasih. ${ }^{55}$ Masing-masing teologi memang memiliki keunikan tersendiri namun tetap saling melengkapi dan memiliki nuansa kesatuan yang harmonis. Yang menarik adalah pandangan Schaff tentang kesatuan dalam keragaman dalam Perjanjian Baru ini sudah ditulis sekitar 1910, jauh sebelum karya James Dunn berjudul Unity and Diversity in the New Testament terbit. ${ }^{56}$

Menurut Schaff terdapat empat tipe dari doktrin rasuli (Apostolic Doctrine), yaitu: Surat Yakobus berhubungan dengan Injil Matius; Surat-surat Petrus dan pidato-pidatonya dalam Kisah Para Rasul berhubungan dengan Injil Markus; Surat-surat Paulus berhubungan dengan Injil Lukas dan Kisah Para Rasul; dan Suratsurat Yohanes berhubungan dengan Injil Yohanes. Pembagian ini berada dalam kategorisasi yang lebih besar, yaitu Kekristenan Yahudi dan Kekristenan non-Yahudi (Gentile), yang berlangsung sepanjang sejarah periode apostolik dan mempengaruhi doktrin, sikap, penyembahan, serta kehidupan praktis dalam gereja. ${ }^{57}$ Masing-masing teologi memiliki keunikan yang khas, namun masih dalam kerangka dasar teologi Gereja Perdana yang mencerminkan kesatuan. Tentunya ruang yang terbatas tidak mengizinkan untuk membahas satu demi satu dari keempat teologi ini, karena hal ini memerlukan pembahasan tersendiri.

Diskusi di atas membawa pada kesimpulan bahwa kemungkinan jawaban (c) adalah yang paling dapat diterima, yaitu bahwa memang ada friksi dalam Gereja Perdana namun secara keseluruhan ada kesatuan di antara teologi Paulus maupun Kekristenan Yahudi; hal ini dapat disebut sebagai Kesatuan dalam Perbedaan (unity in diversity).

${ }^{54}$ Ibid., 67-68.

55 Philip Schaff, History of the Christian Church, Volume I: Apostolic Christianity. A.D. 1-100 (Dallas, TX: The Electronic Bible Society, 1998), 439-478.

${ }^{56}$ Dunn, Unity and Diversity.

${ }^{57}$ Schaff, 437. 
Selanjutnya bagian berikut akan membahas secara ringkas pertanyaan penting lain yang berkaitan erat dengan pertanyaan mengenai relasi antara Paulus dan Kekristenan Yahudi dalam Gereja Perdana, yaitu: apakah Paulus adalah penerus ajaran Yesus ataukah pendiri sesungguhnya Kekristenan? ${ }^{58}$

\section{Apakah Paulus adalah Pendiri Sesungguhnya Kekristenan?}

Memang sudah banyak kajian yang dilakukan untuk menjawab pertanyaan mengenai apakah Paulus adalah pendiri sesungguhnya Kekristenan.

Pertama-tama, perlu diakui seperti disebut di awal tulisan ini bahwa para pemikir muslim umumnya beranggapan bahwa gelar Yesus sebagai Anak Allah diimpor oleh Paulus entah dari paganisme Romawi atau Helenisme. Namun dari sejarah kita justru belajar bahwa Gereja Perdana dapat menerima keilahian Yesus hingga munculnya gerakan Ebionit yang tampil pasca revolusi Bar Kokhba. Karena itu perlu dibahas di sini apakah pandangan kaum Ebionit yang menolak karakter ketuhanan Yesus tersebut berakar dari Kekristenan Yahudi dari masa yang lebih awal. Dalam hal ini perlu dicatat bahwa Dunn menyatakan: sejak abad pertama orang-orang Kristen Yahudi dapat menerima keilahian Yesus, sehingga menempatkan diri mereka bertentangan dengan pandangan bahwa Yesus hanyalah seorang guru yang baik yang merupakan ciri dari Ebionisme. ${ }^{59}$ Dengan kata lain, tidaklah benar tuduhan sebagian orang bahwa ajaran Perjanjian Baru tentang Yesus sebagai Anak Allah merupakan rekaan Gereja pada saat Konsili Nicea (325 M), dan tidak mencerminkan keyakinan Gereja Perdana. Sekali lagi perlu ditegaskan di sini bahwa teologi Gereja Perdana tentang Yesus sebagai Anak Allah tidak dapat disamakan dengan teologi Ebionisme.

Kedua, perlu dicatat bahwa meskipun ada sementara dugaan bahwa sebutan kyrios (Tuhan) bagi Yesus berasal dari kepercayaan pagan Helenistik, Fitzmyer mengajukan pandangan bahwa penggunaan absolut dari kyrios terhadap Yesus tersebut berasal dari latar belakang Palestina-Semitik. ${ }^{60}$ Fitzmyer juga menyatakan bahwa gelar "adon" (Ibr.), yang merupakan akar kata dari sebutan "adonai",

58 David Wenham, Paul: Follower of Jesus or Founder of Christianity? (Grand Rapids, Michigan: Wm. B. Eerdmans Publ. Co., 1995). Untuk tinjauan ringkas atas buku ini, lihat Andreas J. Köstenberger, Trinity Journal 16 (1995): 259-62.

${ }^{59}$ Dunn, Unity and Diversity, 262.

${ }^{60}$ Joseph A. Fitzmyer, S.J., To Advance the Gospel: New Testament Studies, second ed. (Grand Rapids, Michigan: Wm. B. Eerdmans Publ. Co., 1998), 221. 
berasal dari sebutan masyarakat Yahudi Palestina untuk menyebut Yahweh, dan kemudian dilanjutkan oleh jemaat Kekristenan Yahudi Palestina untuk memanggil Yesus. Dengan demikian penggunaan gelar yang sama untuk Yesus mengindikasikan adanya kristologi yang lebih tinggi untuk Dia daripada gelar kyrios yang diturunkan dari konteks pagan Helenistik dari dunia Mediteranian timur. Jadi pengakuan kristologis dari Kyrios Iesous berakar dari Palestina sendiri (I Kor. 12:3; Rom. 10:9). ${ }^{61}$ Sebagai tambahan, pengakuan iman bahwa Yesus adalah Anak Allah dapat ditelusuri kepada pengakuan para rasul semasa Yesus masih di dunia misalnya dari pernyataan Petrus (Mat. 16:16). Sementara itu pasca kebangkitan, Tomas juga menyatakan pengakuannya bahwa Yesus adalah Tuhan dan Allah baginya (Yoh, 20:28). Gelar Anak Allah untuk Yesus juga merupakan salah satu pokok yang sering diperdebatkan hingga saat ini. Adolf Deissman, misalnya, melihat kedekatan antara gelar Anak Allah tersebut dengan kepercayaan Romawi: divi filius (theou buios), namun para ahli yang lain seperti Bousset tidak begitu yakin bahwa gelar tersebut berasal dari kepercayaan pagan Helenistik. ${ }^{62}$ Dalam bab lain di buku yang sama, Fitzmyer mengajukan argumen bahwa berdasarkan temuan naskah Qumran Gua ke-4 (4Q246) terdapat bukti bahwa gelar Anak Allah tersebut berasal dari latar belakang Palestina-Yahudi. ${ }^{63}$ Fitzmyer juga menunjukkan bahwa ada latar belakang Perjanjian Lama (misalnya Mzm. 2) dan bukti penggunaan gelar Anak Allah ini oleh masyarakat pra-Kekristenan Yahudi. ${ }^{64}$

Ketiga, tidak benar bahwa ajaran Paulus menyimpang dari misi Yesus yang bersifat universal. Sebagaimana disimbolkan oleh pengakuan orang-orang Majus yang datang dari jauh (Mat. 2:1-2), dan juga oleh nubuat Simeon: 'keselamatan yang dari pada-Mu, yang telah Engkau sediakan di hadapan segala bangsa,..." (Luk. 2:30-31). Hal ini juga jelas dari kisah Petrus yang perlu diyakinkan dulu dengan penglihatan sebelum diutus untuk menemui Kornelius; baru belakangan Petrus membela pertobatan Kornelius. Petrus juga mengakui adanya larangan keras bagi orang Yahudi untuk bergaul dengan orang-orang bukan Yahudi (Kis. 10:28-29). Tampaknya Paulus dapat membebaskan diri dari bias Yahudi dan tidak menjadi enggan untuk pergi kepada bangsa-bangsa non-Yahudi, tidak seperti

${ }^{61}$ Ibid., 223. Untuk diskusi pembanding, lihat ulasan James Dunn tentang "Jesus as god/God" dalam James D.G. Dunn, Did the First Christians Worship Jesus? The New Testament Evidence (London: Society for Promoting Christian Knowledge, 2010; Louisville: Westminster John Knox Press, 2010), 132-136.

${ }^{62}$ Fitzmyer, The Dead Sea Scrolls and Christian Origins, 64.

${ }^{63}$ Ibid., 41-62.

${ }^{64}$ Ibid., 72. 
rasul-rasul lainnya. Hal ini juga dikatakan oleh Morgan, yaitu bahwa dalam hal misi pewartaan Injil kepada bangsa-bangsa non-Yahudi, Paulus jauh lebih dekat dengan universalitas misi Yesus. ${ }^{65}$

Keempat, mengenai tuduhan bahwa Paulus adalah pendiri sebenarnya dari Kekristenan, jelas hal ini akan ditolak oleh Paulus sendiri. Hal ini dapat dengan mudah dilihat dari pembukaan suratsurat Paulus, ketika ia seringkali menyebut dirinya sebagai hamba Kristus Yesus (lih. Rom.1:1; 1 Kor. 4:1; 7:22; Gal. 1:10; Fil. 1:1). Sebagaimana ditegaskan oleh David Wenham dalam kesimpulan bukunya tentang Paulus: "For him, the fountain of theology was Jesus: first, the Jesus whom he met on the Damascus road; second, the Jesus of the Christian tradition...Paul saw himself as the slave of Jesus Christ, not the founder of Christianity." jelas bahwa Paulus melihat dirinya sendiri sebagai hamba Kristus Yesus, dan bukan sebagai pendiri Kekristenan. Kiranya kesimpulan Wenham tersebut cukup jelas bagi studi tentang Paulus.

Masih banyak kajian lain yang telah dilakukan untuk menjawab pertanyaan mengenai apakah Paulus memang pendiri sebenarnya Kekristenan, namun kiranya apa yang diuraikan di sini dapat memberikan gambaran yang memadai. Salah satu studi tentang Paulus yang bisa disebut dalam konteks ini adalah karya N.T. Wright, ${ }^{67}$ namun tampaknya dia membawa pesan sendiri yang kemudian dikenal sebagai New Perspectives on Paul (NPP). Ada beberapa tinjauan kritis tentang buku N.T. Wright tersebut yang dapat dengan mudah diperoleh secara online. ${ }^{68}$ Namun diskusi tentang topik ini memerlukan makalah tersendiri.

${ }^{65}$ David Lincicum, "F.C. Baur's place in the Study of Jewish Christianity;" diambil dari http://www.davidlincicum.files.wordpress.com/2012/12/fc-baur-onjewish-christianity.pdf ; Internet; diakses 11 Januari 2015.

66 Wenham, 409-410.

${ }^{67}$ N.T Wright, What Saint Paul Really Said: Was Paul of Tarsus the Real Founder of Christianity? (Grand Rapids: Eerdmans, Cincinnati: Forward Movement Publications, 1997), 192 pp.

${ }^{68}$ Lihat Richard B. Gaffin, Jr., "Review Essay: Paul the Theologian," WTJ 62 (2000) 121-41; diambil dari http://www.wtsbooks.com/common/pdf/links/WTJPaulTheTheologian.pdf; Internet; diakses 10 Januari 2015. Juga Tom Hicks, Review on N.T Wright: What Saint Paul Really Said, Was Paul of Tarsus the Real Founder of Christianity, Reformed Baptist Theological Review 01:2 (July 2004). 


\section{Penutup}

Salah satu pertanyaan yang cukup menarik untuk didiskusikan dalam hubungannya dengan sejarah Gereja Perdana adalah sejauh mana ada kesatuan atau perbedaan antara pandangan Petrus, Yakobus dan Paulus, serta sejauh mana pemikiran Paulus menentukan arah perkembangan Gereja di periode-periode selanjutnya. Jawaban atas pertanyaan tersebut akan sangat membantu kita dalam memberikan respons terhadap tuduhan Paulinisme yang kerap dilontarkan oleh beberapa penulis khususnya di Indonesia terhadap ajaran Kekristenan. Tuduhan Paulinisme itu intinya menyatakan bahwa Kekristenan adalah agama buatan Paulus, bukan Yesus Kristus. Dengan perkataan lain, tuduhan ini menyatakan bahwa Paulus adalah pendiri sebenarnya dari Kekristenan. Dan tampaknya tuduhan ini merupakan sikap kalangan muslim pada umumnya, tidak hanya di Indonesia. ${ }^{69}$ Karena itu menjadi kewajiban umat Kristen khususnya kalangan teolog untuk menanggapi tuduhan tersebut secara proporsional. Dalam artikel ini penulis hendak menjelaskan bagaimana sebenarnya relasi antara Paulus dengan Gereja Yerusalem secara umum, dan relasi antara Paulus dengan Yakobus saudara Yesus secara khusus, dengan tujuan untuk menjawab apakah benar tuduhan Paulinisme tersebut. Ditunjukkan bahwa relasi antara Paulus dan Gereja Yerusalem tidak mengindikasikan adanya perpecahan, melainkan kesatuan dalam perbedaan (unity in diversity).

Sebagai kesimpulan, dalam sejarah pemikiran tentang Paulus, ada setidaknya empat kelompok besar gagasan tentang relasi antara Paulus dan Gereja Yerusalem, yaitu: keseragaman (uniformity), kesatuan (unity), perbedaan (diversity), dan perpecahan (conflict). Keempat kelompok pemikiran tersebut dapat ditunjukkan sebagai sebuah garis yang menunjukkan spektrum pemikiran sebagai berikut:

\section{Keseragaman - Kesatuan - Perbedaan - Perpecahan}

Namun, telah ditunjukkan bahwa relasi antara Paulus dan Gereja Yerusalem tidak mengindikasikan adanya perpecahan, melainkan kesatuan dalam perbedaan (unity in diversity).

${ }^{69}$ Lihat misalnya "The True Founder of Christianity;" diambil dari http://www.teachislam.com/dmdocuments/45/The $\% 20$ True $\% 20$ Founder $\% 20$ of \%20Christianity.pdf ; Internet; diakses 8 Januari 2015. 
Artikel ini bertujuan untuk membuka dialog lintas-iman yang lebih konstruktif, meskipun merupakan karya awal sehingga mungkin tidak memberikan kata akhir atau jawaban definitif terhadap persoalan ini. Harapan penulis adalah kiranya artikel ini dapat membantu menjelaskan mengapa tuduhan Paulinisme yang dilontarkan sebagian orang kepada umat Kristen adalah tidak berdasar. Bagi sahabat-sahabat muslim, artikel ini silakan dianggap sebagai undangan untuk melakukan dialog teologis Islam-Kristen yang lebih konstruktif, dan tidak sekadar melontarkan tuduhan Paulinisme yang tidak berdasar dan sudah usang. ${ }^{70}$

\section{Tentang Penulis}

Victor Christianto, MTh., saat ini adalah staf pengajar di Institut Pertanian Malang sekaligus lulusan program pascasarjana dari Sekolah Tinggi Teologi Satyabhakti, Malang (www.sttsati.org). Ia pernah menempuh studi gravitasi dan kosmologi di Institute of Gravitation and Cosmology di Peoples's Friendship University of Russia, Moscow (Desember 2008-Juni 2009), sebelum beralih fokus ke teologi. Bidang minatnya meliputi antara lain: teologi, sejarah Kekristenan Perdana, Naskah-naskah Laut Mati, energi terbarukan dan kosmologi.

${ }^{70}$ Salah satu upaya membangun dialog ke arah itu dipaparkan dalam buku Olaf Schumann, 10 Ulama Bicara Isa Al-Masib dan AjaranNya: Membangun Kesadaran Kritis Hubungan Muslim-Kristen (Jakarta: Elex Media Komputindo, 2013), 338pp. Lihat juga Bambang Noorsena, Menuju Dialog Teologis Kristen-Islam (Yogyakarta: Yayasan ANDI, 2001), 172 pp. 


\section{Daftar Pustaka}

Adams, Sean A. "Paul the Roman Citizen," in Stanley E. Porter (ed.), Paul: Jew, Greek, and Roman. Leiden: Brill, 2008.

Aune, David E. (ed.) The Blackwell Companion to the New Testament. West Sussex: John Wiley \& Sons Ltd., 2010.

Barrett, C.K. On Paul: Essays on His Life, Work, and Influence in the Early Church. London: T\&T Clark Ltd., 2003.

Baur, Ferdinand C. Paul: The Apostle of Jesus Christ, 1845. Vol. I, second ed., diterjemahkan oleh Eduard Zeller. London: Williams \& Norgate, 1876.

Bruce, F.F. Peter, Stephen, James, and John: Studies in Early Non-Pauline Christianity. Grand Rapids, Michigan: Wm. B. Eerdmans Publ. Co., 1980.

Carson, D,A. "Historical Tradition of the Fourth Gospel: After Dodd, what?" R.T. France \& David Wenham, eds., Gospel Perspectives, Vol. 2: Studies of History and Tradition in the Four Gospels. Sheffield: JSOT Press, 1981.

Chilton, Bruce. Preface to Sean Freyne, Retrieving James/Yakov, the Brother of Jesus: From Legend to History. Center for the Study of James the Brother, Institute of Advanced Theology. New York: Bard College, 2008.

Decker, Rodney J. "The Rehabilitation of Heresy: Part 2, "Misquoting" Earliest Christianity," Journal of Ministry and Theology 13:2 (Fall 2009): 57-95.

Dunn, James D.G. Did the First Christians Worship Jesus? The New Testament Evidence. Louisville: Westminster John Knox Press, 2010. . The Partings of the Ways: Between Christianity and Judaism and their significance for the Character of Christianity. Second ed. London: SCM Press, 2006. . Unity and Diversity in the New Testament: An Inquiry into the Character of Earliest Christianity, Second ed., 3rd printing. Tottenham Road, London: SCM Press, 1990.

Dunn, R.P. "The Tübingen Historical School," BSAC 19:73 (Jan. 1862): 85.

Ehrman, Bart D. Lost Scriptures: Books that did not make it to the New Testament. New York: Oxford University Press Inc., 2003.

Eisenman, Robert. James the Brother of Jesus: The Key to Unlocking the Secrets of Early Christianity and the Dead Sea Scrolls. Middlesex, England: Penguin Books, 1997. . "Paul as Herodian", JHC 3/1 (Spring):110-122 [jurnal on-line]; diambil dari http://www.depts.drew.edu/jhc/eisenman.html; Internet; diakses 17 Februari 2014.

Fitzmyer, S.J., Joseph A. To Advance the Gospel: New Testament Studies, second ed. Grand Rapids, Michigan: Wm. B. Eerdmans Publ. Co., 1998. 
Gaffin, Jr., Richard B. "Review Essay: Paul the Theologian,” WTJ 62 (2000) 121-41; diambil dari http://www.wtsbooks.com/common/pdf/links/WTJPaulThe'The ologian.pdf; Internet; diakses 10 Januari 2015.

Gasque, W. Ward. "The Historical Value of the Book of Acts: The Perspective of British Scholarship," Theologische Zeitschrift 28 (1972), 177-196; diambil dari http://www.biblicalstudies.org.uk/; Internet; diakses 8 Januari 2015.

Gonzalez, Justo L. A History of Christian Thought, Rev. Ed. Vol. 1: From the Beginnings to the Council of Chalcedon. Nashville: Abingdon Press, 1987.

Hicks, Tom. "Review on N.T Wright: What Saint Paul Really Said, Was Paul of Tarsus the Real Founder of Christianity," Reformed Baptist Theological Review $1 / 2$ (July 2004): 196-201

Howell, Don N., Jr. "Pauline thought in the History of Interpretation," $B S A C$ 150:599 (Jul 1993): 303-26.

Jabbour, Nabeel T. Memandang sabit melalui mata salib. Bandung: Pionir Jaya, 2010.

Jacobs, T. Paulus - Hidup, Karya dan Teologinya. Cet.-2. Yogyakarta: Penerbit Yayasan Kanisius, 1983; Jakarta: B.P.K. Gunung Mulia, 1984.

Khoo, Jeffrey. "Heresies Ancient and Modern," [artikel on-line]; diambil dari http://www.febc.edu.sg/assets/pdfs/studyresource/heresies.pdf; Internet; diakses 17 April 2014.

Köstenberger, Andreas J. Trinity Journal 16 (1995): 259-62.

Lincicum, David. "F.C. Baur's place in the Study of Jewish Christianity;" diambil dari http://www.davidlincicum.files.wordpress.com/2012/12/fc-bauron-jewish-christianity.pdf; Internet; diakses 11 Januari 2015.

Noorsena, Bambang. Menuju Dialog Teologis Kristen-Islam. Yogyakarta: Yayasan ANDI, 2001, 172 pp.

Pagels, Elaine. "The Text of the Gospel of Thomas." Polebridge Press, 2004 [artikel on-line]; diambil dari http://www.holybooks.com/wp-content/uploads/Gospel-ofThomas-Scholars-Version.pdf; Internet; diakses 3 Agustus 2014.

Peyton, Harry A. "The Heresies of the Pharisaical Jewish Christian Ebionites," [artikel on-line]; diambil dari http://www.doctrinesofchrist.com/The $\% 20$ Heresies $\% 20$ of $\% 20$ th e\%20Pharisaical\%20Jewish\%20Ebionites.pdf; Internet; diakses 17 April 2014.

Roberts, Alexander \& Donaldson, James. Ante-Nicene Fathers: The Writings of the Fathers Down to A.D. 325. Vol. 8, rev. ed. Peabody, Massachussets: Hendrickson Publishers Inc., 1994.

Schaff, Philip. History of the Christian Church, Volume I: Apostolic Christianity. A.D. 1-100. Dallas, TX: The Electronic Bible Society, 1998.

Schmithals, Walter. Paul and James. Studies in Biblical Theology no. 46. Great Britain: SCM Press Ltd., 1965, 106. 
Schonfield, Hugh J. The History of Jewish Christianity: From the First to the Twentieth Century. Duckworth, London: Vine of David, 1936.

Schumann, Olaf. 10 Ulama Bicara Isa Al-Masih dan AjaranNya: Membangun Kesadaran Kritis Hubungan Muslim-Kristen. Jakarta: Elex Media Komputindo, 2013.

Scott, Jr., J. Julius. "Parties in the Church of Jerusalem as seen in the book of Acts", JETS 18:4 (Fall 1975): 217 [jurnal on-line]; diambil dari http://galaxie.com/journals; Internet; diakses 24 Februari 2014.

Skarsaune, Oskar \& Hvalvik, Reidar (eds.) Jewish Believers in Jesus: The Early Centuries. Peabody, Massachusetts: Hendrickson Publishers Inc., 2007.

Stambaugh, John \& Balch, David. Dunia sosial kekeristenan mula-mula. Cet.-2. Diterjemahkan oleh Stephen Suleeman. Jakarta: PT BPK Gunung Mulia, 1997.

Taylor, Justin. Asal-usul Agama Kristen. Diterjemahkan oleh F.A. Suprapto.Yogyakarta: Penerbit Kanisius, 2008.

Taylor, Nicholas. "Paul, Antioch and Jerusalem: A Study in Relationships and Authority in Earliest Christianity," Journal for the Study of the New Testament, Supplement Series 66. Sheffield: Sheffield Academic Press, 1992.

Wenham, David. Paul: Follower of Jesus or Founder of Christianity? Grand Rapids, Michigan: Wm. B. Eerdmans Publ. Co., 1995.

Wright, N.T. What Saint Paul Really Said: Was Paul of Tarsus the Real Founder of Christianity? Grand Rapids: Eerdmans, Cincinnati: Forward Movement Publications, 1997.

Young, Brad H., Paul The Jewish Theologian: A Pharisee among Christians, Jews, and Gentiles. Grand Rapids, Michigan: Baker Academic, 1995. 